\title{
Snap beans for organic farming and evaluation of resistance to the common bacterial blight
}

\author{
Felipe A Andrade'; Leandro SA Gonçalves ${ }^{1}$; Anderson Fukujii'; Édison Miglioranza ${ }^{1}$; Lúcia SA Takahashi'; \\ Maria I Balbi-Peña ${ }^{1}$; Rosana Rodrigues ${ }^{2}$ \\ ${ }^{1}$ Universidade Estadual de Londrina (UEL), Londrina-PR, Brasil; felipearanhaa@hotmail.com; leandrosag@uel.br; andersonfukuji@hotmail. \\ com; emiglior@uel.br; luciasadayo@gmail.com; mariabalbi@uel.br; ${ }^{2}$ Universidade Estadual do Norte Fluminense Darcy Ribeiro (UENF), \\ Campos dos Goytacazes-RJ, Brasil; rosana@uenf.br
}

\begin{abstract}
Snap beans have been widely used in organic farming as a good income source and an alternative to diversify production, with increasing use in crop rotation. This work reports the evaluation of 25 bush-type snap beans accessions for their suitability to integrate a breeding program for organic farming, as well as for their resistance to the common bacterial blight (CBB). Agronomic performance was assessed in two field experiments (September-December, 2013; April-June, 2014), in complete blocks at random, while resistance to CBB was assessed in greenhouse, in a completely randomized trial. Plants were challenged with two isolates, one from Xanthomonas axonopodis pv. phaseoli and another from $X$. fuscans subsp. fuscans. Accessions UEL 402, UEL 405, UEL 407, UEL 408, UEL 412 , UEL 417 and UEL 420 were highly productive in both seasons (averages of 10.3, 8.7, 9.5, 9.2, 8.9, 9.3 and 9.2 t/ha, respectively), and are promising for use both as cultivars by organic farmers in the region of Londrina and also as germplasm in breeding programs for developing cultivars adapted to the region. Although all accessions were moderately susceptible to CBB, accessions UEL 407, UEL 409, UEL 411, UEL 412, UEL 424 and UEL 431 presented the lowest values for the area under CBB progress curve for both isolates.
\end{abstract}

Keywords: Phaseolus vulgaris, Xanthomonas axonopodis, Xanthomonas fuscans, smallholders, agroecology.

\section{RESUMO}

Feijão de vagem para cultivo orgânico e avaliação da resistência ao crestamento bacteriano comum

O feijão de vagem vem sendo amplamente utilizado na agricultura orgânica por ser uma boa fonte de renda e uma alternativa para diversificar a produção, com uso crescente em rotação de culturas. Os objetivos deste trabalho foram avaliar 25 acessos de feijão de vagem de hábito determinado para uso em um programa de melhoramento para cultivo orgânico e verificar o nível de resistência destes acessos ao crestamento bacteriano comum (CBC). O desempenho agronômico foi avaliado em dois experimentos de campo (setembro-dezembro, 2013; abril-junho, 2014), em blocos ao acaso; e sua resistência ao $\mathrm{CBC}$ foi avaliada em um experimento em casa de vegetação, inteiramente ao acaso. Foram utilizados dois isolados, um de Xanthomonas axonopodis pv. phaseoli e outro $X$. fuscans subsp. fuscans. Os acessos UEL 402, UEL 405, UEL 407, UEL 408, UEL 412, UEL 417 e UEL 420 apresentaram elevada produtividade para ambas as épocas (médias de 10,3, 8,7, 9,5, 9,2, 8,9, 9,3 e 9,2 t/ha, respectivamente), sendo considerados promissores para uso tanto como cultivares pelos produtores orgânicos da região de Londrina, quanto como germoplasma em programas de melhoramento visando o desenvolvimento de cultivares adaptadas à região. Embora todos os acessos tenham sido moderadamente suscetíveis ao CBC, os acessos UEL 407, UEL 409, UEL 411, UEL 412, UEL 424 e UEL 431 apresentaram valores menores para área abaixo da curva do progresso do crestamento bacteriano para ambos os isolados.

Palavras-chave: Phaseolus vulgaris, Xanthomonas axonopodis, Xanthomonas fuscans, agricultura familiar, agroecologia.

\section{Received on June 8, 2016; accepted on February 21, 2017}

$\mathrm{S}^{\mathrm{n}}$ nap beans (Phaseolus vulgaris) are considered one of the world's main vegetables, reaching an annual estimated production around 21 million tons (FAO, 2015). In Brazil, production figures and information on the importance of snap beans market are scarce. Snap beans are widely grown by Brazilian smallholders, representing a good source of income and as an alternative to diversify production, either through crop rotation, an increasingly popular practice, or as option during off-season of other vegetables.

Snap beans cultivars are classified according to growth habit and pod type and color. Pole-type cultivars are preferred in Brazil, since usually they outyield bush types. However, pole-type snap beans are more labor intense than bush-types: pole-types need tutoring and have higher incidence of pests and diseases due to their larger cycles (Moreira et al., 2009). There are two main types of pods: butter and flat; and four basic color groups: dark green, light green, yellow and purple (Myers \& Baggett, 1999).

Despite the economic and social importance of snap beans, breeding programs for organic farming are scarce. Organic farming, considered a sustainable cropping system, has been 
expanding steadily in last decades in several countries (Willer \& Kilcher, 2012). In Brazil, 10,505 farmers currently meet official organic farming requirements, a 56\% increase when compared to 2013, when not more than 6.7 thousand farmers were accredited as organic producers (MAPA, 2015).

Vegetable production is pioneer in organic farming. Even though, it still faces difficulties as, for instance, lack of enough organic seeds to meet the certification process throughout the production chain. In addition, cultivars meant for organic farming should be developed according to agroecological principles, using germplasm adapted to local conditions. Very often, in comparative experiments between conventional and organic systems, cultivars with good performance in the first do not necessarily perform well in the second (Kirk et al., 2012, Spagnuolo et al., 2016). In organic farming, the ideal cultivar is expected to be rustic, resistant to pests and diseases and reasonably productive in the absence of soluble fertilizers (Vidal et al., 2007).

Among snap beans diseases, the common bacterial blight (CBB), caused by Xanthomonas axonopodis pv. phaseoli (Xap) or X. fuscans subsp. fuscans (Xff) (EFSA Panel on Plant Health, 2014), is considered the main bacterial disease affecting beans in Brazil (Trindade et al., 2012; Silva et al., 2013). Xap and Xff are present in all environments where $P$. vulgaris is produced, causing damage mainly under high temperature and humidity (Miklas et al., 2003). CBB symptoms are observed throughout plant aboveground part: leaves, stems, pods and seeds (Rava \& Sartorato, 1994). At first, leaves show water-soaked lesions that evolve into necrotic spots, usually surrounded by a yellow halo. Adjacent lesions coalesce and, in severe infections, CBB causes leaf death and, consequently, plant defoliation. In pods, lesions are initially circular and soaked, becoming necrotic and reddish. Seeds present discoloration in the thread, spots on the tegument and wrinkling, although in some cases seed infection is symptomless (Bianchini et al., 2005).

CBB must be controlled by employing several management measures simultaneously, since bactericides alone are not efficient. Among recommended measures, the use on non-infested areas, healthy seeds, crop rotation, adequate irrigation systems and resistant cultivars are highlighted (Trindade et al., 2015). Nevertheless, the development of snap beans cultivars with resistance to $\mathrm{CBB}$ is a challenge to breeders. Breeding for CCB resistance in snap beans still waits for the identification of resistance sources in either snap beans or common beans, once high levels of resistance to Xanthomonas spp. have not been found in $P$. vulgaris yet.

The present work describes the screening of accessions of bush-type snap beans from the Germplasm Bank of the Universidade Estadual de Londrina (UEL) for their performance in organic farming and resistance to CBB.

\section{MATERIAL AND METHODS}

Twenty-five snap beans accessions from the germplasm bank of the Universidade Estadual de Londrina (UEL) were evaluated. Agronomic traits were assessed in two experiments carried out at UEL School Farm (2320'23'S, $51^{\circ} 12^{\prime} 32^{\prime}$ ' $\mathrm{W}$, altitude $535 \mathrm{~m}$ ), in an area kept under organic farming for five years. Experiment I was carried out from September to December 2013 and, experiment II, from April to June 2014.

The farm is located under mesothermal humid subtropical climate Cfa (Köppen classification), with hot summers, winters with frequent and severe frost, and no marked dry season. The average annual temperature is $20^{\circ} \mathrm{C}$. The soil, a Rhodic Ferralsol, had the following characteristics: $\mathrm{pH}_{\mathrm{H} 2 \mathrm{O}}=$ 5.5; $\mathrm{P}=3.41 \mathrm{cmolc} / \mathrm{dm}^{3} ; \mathrm{K}^{+}=0.74$ $\mathrm{cmolc} / \mathrm{dm}^{3} ; \mathrm{Ca}^{+2}=6.8 \mathrm{cmolc} / \mathrm{dm}^{3}$; $\mathrm{Mg}^{+2}=1.2 \mathrm{cmolc} / \mathrm{dm}^{3} ; \mathrm{Al}^{+3}=0.05$; $\mathrm{H}+\mathrm{Al}=4.28 \mathrm{cmolc} / \mathrm{dm}^{3} ; \mathrm{CEC}=13.02$ cmolc/dm 3 ; V $=67.13 \%$ and Organic Matter $=1.87 \%$.

Experiments were set in complete blocks at random, with three replications, 20 -plant plots, and $0.2 \times 0.45 \mathrm{~m}$ spacing between plants and rows, respectively. In both experiments, fertilization consisted of $10 \mathrm{t} /$ ha of organic compost with the following chemical composition: $\mathrm{pH}_{\mathrm{H} 2 \mathrm{O}}$ $=7.2 ; \mathrm{P}=359.30 \mathrm{mg} / \mathrm{dm}^{3} ; \mathrm{K}^{+}=5.78$ cmolc $/ \mathrm{dm}^{3} ; \mathrm{Ca}^{+2}=9.5 \mathrm{cmolc} / \mathrm{dm}^{3} ; \mathrm{Mg}^{+2}=$ $6.9 \mathrm{cmolc} / \mathrm{dm}^{3} ; \mathrm{Al}^{+3}=0.0 ; \mathrm{H}+\mathrm{Al}=2.19$ $\mathrm{cmolc} / \mathrm{dm}^{3} ; \mathrm{CEC}=24.37 \mathrm{cmolc} / \mathrm{dm}^{3} ; \mathrm{V}=$ $91.01 \%$ and Organic Matter $=5.5 \%$. We used sprinkling irrigation to water the plants, straw between plants and lines to inhibit weeds, and the Bordeaux mixture $(0.5 \%)$ before flowering to control diseases. Agronomic performance was measured by means of number of commercial (NCP) and non-commercial pods (NnCP) per plant, mass of commercial pods (MCP), in grams, and commercial yield (Yield), in t/ha, considering pods longer than $10 \mathrm{~cm}$, with no mechanical or disease damages, as commercial.

CBB resistance was evaluated in greenhouse, at the Department of Agronomy (UEL), from December 2013 to February 2014. We used a completely randomized design and with ten replications. Accessions were grown in five-liter pots, filled with a 50\%-soil $/ 30 \%$-manure $/ 20 \%$-sand substrate. We planted four seeds per pot, thinned after emergence to two plants per pot.

Inoculation was carried out 35 days after sowing with two bacterial isolates, Xanthomonas axonopodis pv. phaseoli (Xap), and X. fuscans subsp. fuscans (Xff), received from the Biological Institute of São Paulo and from the Agronomic Institute of Paraná, respectively. Isolates were cultured in DYGS medium (Rodrigues Neto et al., 1986) in Petri dishes (streaks made with smear loop) and kept in growth chamber, $28^{\circ} \mathrm{C}$ for 36 hours. After, bacterial colonies were suspended in $100 \mathrm{~mL}$ distilled water and concentration adjusted to $10^{7}$ $\mathrm{CFU} / \mathrm{mL}$, using a spectrophotometer at $640 \mathrm{~nm}$ absorbance. For inoculation, we took a three-blade leaf per plant and inoculated each bacterial isolate in a separate leaflet. Inoculation consisted of two 2-cm cuts per leaflet made with scissors previously immersed in the two bacterial suspensions.

CBB severity was evaluated daily for 30 days, using the diagrammatic scale of Pastor-Corrales et al. (1981), where: $1=$ no symptoms; $2=1$ to $5 \%$ necrosis; $3=6$ to $25 \%$ necrosis; $4=26$ to $50 \%$ 
necrosis; $5=$ over $50 \%$ necrosis. Data were used to calculate the area under the disease progress curve (AUDPC). Data from field and greenhouse experiments were submitted to analysis of variance individually and, subsequently, once homogeneity of residual variances was detected, field experiments were submitted to joint analysis of variance. Means were grouped using the ScottKnott test, at 5\% significance, whenever significant differences were found. Data were analyzed with the aid of the R program (http://www.r-project.org) using the Agricolae and Scott-Knott packages.

\section{RESULTS AND DISCUSSION}

The analysis of variance carried out independently for each field experiment indicated the occurrence of significant differences among snap beans genotypes for number of commercial and noncommercial pods per plant and productivity in season I; and for mass of commercial pods and productivity in season II, pointing to a wide variability among snap beans accessions. Accuracy estimates had moderate $(\geq 50<70)$, high $(\geq 70<90)$ or very high $(\geq 90)$ magnitude in all cases, confirming experimental precision (Cargnelutti Filho et al., 2009). Accuracy is a very robust indicator of experimental precision, since the experimental mean does not influence it (Resende \& Duarte, 2007).

Cargnelutti Filho et al. (2009) consider selective accuracy more adequate to assess experimental precision in trials with beans than the coefficient of variation or the honest significant difference used on the Tukey test, as percentage of the mean. The $\mathrm{F}$ test for the joint analysis of variance carried out considering the two field experiments indicated significant differences for all traits, for both sources of variation, e.g., genotypes and environments (seasons). Genotype $\mathrm{x}$ environment interaction (GE) was significant for all traits as well, indicating a differential response from genotypes to the environmental variation.

Agronomic traits averages were higher for the experiment carried out from April to June 2014 (Season II)

Table 1. Number of commercial and non-commercial pods per plant, mass and yield of commercial pods of 25 bush-type snap beans. Londrina, UEL, 2013.

\begin{tabular}{|c|c|c|c|c|c|c|c|c|}
\hline \multirow[t]{2}{*}{ Genotypes } & \multicolumn{2}{|c|}{$\begin{array}{c}\text { Number of commercial } \\
\text { pods/plant }\end{array}$} & \multicolumn{2}{|c|}{$\begin{array}{c}\text { Number of non-commercial } \\
\text { pods/plant }\end{array}$} & \multicolumn{2}{|c|}{$\begin{array}{l}\text { Mass of commercial } \\
\text { pods (g) }\end{array}$} & \multicolumn{2}{|c|}{$\begin{array}{l}\text { Yield of commercial } \\
\operatorname{pods}(\mathrm{t} / \mathrm{ha})\end{array}$} \\
\hline & $\operatorname{Exp} I$ & $\overline{\operatorname{Exp}}$ II & $\operatorname{Exp} I$ & $\operatorname{Exp}$ II & $\operatorname{Exp} I$ & Exp II & $\operatorname{Exp} I$ & Exp II \\
\hline UEL 402 & $9.7 \mathrm{Aa}$ & $10.6 \mathrm{Aa}$ & $52.3 \mathrm{Aa}$ & $35.0 \mathrm{Aa}$ & $9.0 \mathrm{Aa}$ & $9.3 \mathrm{Ab}$ & $9.7 \mathrm{Aa}$ & $10.9 \mathrm{Aa}$ \\
\hline UEL 403 & $5.8 \mathrm{Bb}$ & $9.0 \mathrm{Aa}$ & $34.7 \mathrm{Ab}$ & $24.7 \mathrm{Aa}$ & $10.3 \mathrm{Aa}$ & $10.5 \mathrm{Aa}$ & $6.7 \mathrm{Bb}$ & $10.6 \mathrm{Aa}$ \\
\hline UEL 404 & $6.3 \mathrm{Bb}$ & $9.6 \mathrm{Aa}$ & $29.3 \mathrm{Ab}$ & $34.0 \mathrm{Aa}$ & 8.9 Aa & $9.9 \mathrm{Aa}$ & $6.2 \mathrm{Bb}$ & $10.5 \mathrm{Aa}$ \\
\hline UEL 405 & $7.3 \mathrm{Bb}$ & 9.6 Aa & $39.3 \mathrm{Ab}$ & $37.0 \mathrm{Aa}$ & $9.8 \mathrm{Aa}$ & $9.1 \mathrm{Ab}$ & $8.0 \mathrm{Aa}$ & 9.7 Aa \\
\hline UEL 407 & $9.6 \mathrm{Aa}$ & $9.6 \mathrm{Aa}$ & $41.0 \mathrm{Ab}$ & $30.3 \mathrm{Aa}$ & $8.8 \mathrm{Aa}$ & $8.9 \mathrm{Ab}$ & $9.4 \mathrm{Aa}$ & $9.5 \mathrm{Aa}$ \\
\hline UEL 408 & $9.0 \mathrm{Aa}$ & $10.4 \mathrm{Aa}$ & $35.0 \mathrm{Ab}$ & $35.0 \mathrm{Aa}$ & $9.0 \mathrm{Aa}$ & $8.5 \mathrm{Ab}$ & $9.0 \mathrm{Aa}$ & $9.3 \mathrm{Aa}$ \\
\hline UEL 409 & $8.0 \mathrm{Ba}$ & $10.5 \mathrm{Aa}$ & $34.3 \mathrm{Ab}$ & $34.0 \mathrm{Aa}$ & $8.5 \mathrm{Aa}$ & $8.2 \mathrm{Ab}$ & 7.6 Ab & $9.3 \mathrm{Aa}$ \\
\hline UEL 411 & $12.0 \mathrm{Aa}$ & $8.3 \mathrm{Ba}$ & $35.3 \mathrm{Ab}$ & $32.0 \mathrm{Aa}$ & 7.2 Aa & $8.3 \mathrm{Ab}$ & $9.5 \mathrm{Aa}$ & $7.0 \mathrm{Bb}$ \\
\hline UEL 412 & $8.5 \mathrm{Aa}$ & $9.0 \mathrm{Aa}$ & $38.7 \mathrm{Ab}$ & $32.0 \mathrm{Aa}$ & $8.4 \mathrm{Aa}$ & $10.2 \mathrm{Aa}$ & 7.8 Ba & $10.1 \mathrm{Aa}$ \\
\hline UEL 415 & $7.1 \mathrm{Bb}$ & $10.1 \mathrm{Aa}$ & $32.0 \mathrm{Ab}$ & $31.3 \mathrm{Aa}$ & $9.4 \mathrm{Aa}$ & $9.8 \mathrm{Aa}$ & 7.4 Bb & $11.0 \mathrm{Aa}$ \\
\hline UEL 416 & $6.1 \mathrm{Ab}$ & 7.4 Aa & $54.0 \mathrm{Aa}$ & $57.3 \mathrm{Aa}$ & $8.7 \mathrm{Ba}$ & $11.0 \mathrm{Aa}$ & $5.9 \mathrm{Bb}$ & 8.9 Aa \\
\hline UEL 417 & 7.9 Aa & 8.4 Aa & $43.7 \mathrm{Ab}$ & $29.0 \mathrm{Aa}$ & $9.8 \mathrm{Aa}$ & $11.0 \mathrm{Aa}$ & $8.6 \mathrm{Aa}$ & $10.0 \mathrm{Aa}$ \\
\hline UEL 420 & $9.5 \mathrm{Aa}$ & $8.2 \mathrm{Aa}$ & $34.3 \mathrm{Ab}$ & $34.3 \mathrm{Aa}$ & $8.7 \mathrm{Aa}$ & $10.1 \mathrm{Aa}$ & $9.2 \mathrm{Aa}$ & $9.2 \mathrm{Aa}$ \\
\hline UEL 424 & $5.6 \mathrm{Bb}$ & $8.7 \mathrm{Aa}$ & $39.7 \mathrm{Ab}$ & $20.3 \mathrm{Aa}$ & $8.1 \mathrm{Ba}$ & $11.0 \mathrm{Aa}$ & $5.1 \mathrm{Bb}$ & $10.6 \mathrm{Aa}$ \\
\hline UEL 427 & $5.1 \mathrm{Bb}$ & $8.1 \mathrm{Aa}$ & $37.0 \mathrm{Ab}$ & $28.7 \mathrm{Aa}$ & $9.3 \mathrm{Aa}$ & $10.0 \mathrm{Aa}$ & $5.2 \mathrm{Bb}$ & $9.0 \mathrm{Ab}$ \\
\hline UEL 429 & 9.9 Aa & 7.8 Aa & $19.3 \mathrm{Bb}$ & 39.7 Aa & $7.5 \mathrm{Ba}$ & $9.9 \mathrm{Aa}$ & $8.3 \mathrm{Aa}$ & $8.5 \mathrm{Ab}$ \\
\hline UEL 431 & $8.3 \mathrm{Aa}$ & $9.8 \mathrm{Aa}$ & $62.7 \mathrm{Aa}$ & $37.3 \mathrm{Ba}$ & 7.2 Aa & $8.8 \mathrm{Ab}$ & $6.6 \mathrm{Bb}$ & $9.6 \mathrm{Aa}$ \\
\hline UEL 436 & $6.2 \mathrm{Bb}$ & $10.8 \mathrm{Aa}$ & $65.7 \mathrm{Aa}$ & $40.0 \mathrm{Ba}$ & $10.0 \mathrm{Aa}$ & $9.2 \mathrm{Ab}$ & $7.0 \mathrm{Bb}$ & $11.1 \mathrm{Aa}$ \\
\hline UEL 441 & $5.0 \mathrm{Bb}$ & $8.8 \mathrm{Aa}$ & $41.7 \mathrm{Ab}$ & $48.7 \mathrm{Aa}$ & $9.4 \mathrm{Aa}$ & $7.8 \mathrm{Ab}$ & $5.2 \mathrm{Bb}$ & $7.5 \mathrm{Ab}$ \\
\hline UEL 445 & $7.0 \mathrm{Bb}$ & $10.2 \mathrm{Aa}$ & $44.0 \mathrm{Ab}$ & $30.0 \mathrm{Aa}$ & $8.9 \mathrm{Aa}$ & $7.5 \mathrm{Ab}$ & $6.9 \mathrm{Ab}$ & $8.4 \mathrm{Ab}$ \\
\hline UEL 446 & $6.4 \mathrm{Ab}$ & 7.1 Aa & $41.3 \mathrm{Ab}$ & $32.7 \mathrm{Aa}$ & $9.8 \mathrm{Aa}$ & $11.1 \mathrm{Aa}$ & $6.9 \mathrm{Ab}$ & $8.7 \mathrm{Ab}$ \\
\hline UEL 447 & 7.2 Ab & $9.2 \mathrm{Aa}$ & $67.3 \mathrm{Aa}$ & $25.0 \mathrm{Ba}$ & $9.2 \mathrm{Aa}$ & $6.3 \mathrm{Bb}$ & 7.4 Ab & $6.5 \mathrm{Ab}$ \\
\hline UEL 1 & 7.9 Aa & $8.8 \mathrm{Aa}$ & $60.0 \mathrm{Aa}$ & $36.3 \mathrm{Ba}$ & $9.8 \mathrm{Aa}$ & $7.8 \mathrm{Bb}$ & $8.5 \mathrm{Aa}$ & 7.6 Ab \\
\hline UEL 2 & 8.2 Aa & 9.6 Aa & $57.0 \mathrm{Aa}$ & $43.7 \mathrm{Aa}$ & 7.8 Aa & $8.3 \mathrm{Ab}$ & $6.9 \mathrm{Ab}$ & $8.7 \mathrm{Ab}$ \\
\hline Alessa & $9.1 \mathrm{Aa}$ & $9.1 \mathrm{Aa}$ & $52.0 \mathrm{Aa}$ & $58.3 \mathrm{Aa}$ & 7.3 Aa & $9.0 \mathrm{Ab}$ & $7.4 \mathrm{Ab}$ & $9.1 \mathrm{Aa}$ \\
\hline
\end{tabular}

Pods longer than $10 \mathrm{~cm}$ with no mechanical or disease damages were considered commercial; Means followed by same capital letters in the line and small letters in the column do not differ significantly from each other by Scott-Knott test, $5 \%$. 
[number of commercial pods per plant (NCP): 9.15; pod mass (PM): $9.26 \mathrm{~g}$; and commercial productivity (PROD): $9.25 \mathrm{t} / \mathrm{ha}$ ] than for experiment carried out between September and December, 2013 (Season I) (NCP: 7.71; PM: 8.84 g; and PROD: $7.46 \mathrm{t} / \mathrm{ha}$ ) (Table 1). The highest pest and disease incidence in season I is likely the most relevant reason associated to differences between environments.

NCP ranged from 5.0 to 12.0 and from 7.1 to 10.8 in seasons I and II, respectively. In season II, accessions did not differ significantly from each other. In season I, best accessions were UEL 402, UEL 408, UEL 409, UEL 411, UEL 412, UEL 417, UEL 420, UEL 429, UEL 431, UEL 1, UEL 2 and cultivar Alessa (Table 1). Moreira et al. (2009), evaluating 14 genotypes of bush-type snap beans in conventional farming, observed NCP varying between 2.2 and 7.1, genotypes HAB 415, HAB 441, HAB 448 and UEL 2 having the highest values. Genotypes HAB 415, HAB 441 and UEL 2 were evaluated also in the present study and accessions HAB 415 and HAB 441 had significantly lower NCPs than accessions clustered in the top group. Comparative trials between conventional and organic farming have already shown that cultivars with good performance in conventional systems do not necessarily perform well in organic farming (Kirk et al., 2012; Luby et al., 2013). Mason \& Spaner (2006) stated that the increase of plant stress in organic farming can affect cultivar performance strongly enough to justify the development of breeding programs specific for organic farming.

No significant differences among accessions were found for $\mathrm{NnCP}$ by the Scott-Knott clustering test in season II. Nevertheless, in season I accessions UEL 402, UEL 416, UEL 431, UEL 436, UEL 447, UEL 1, UEL 2 and cultivar Alessa were grouped as having significantly highest $\mathrm{NnCP}$, respectively $52.3,54.0,62.7,65.7,67.3,60.0,57.0$ and 52.0 (Table 1). Differences may be related to the differential anthracnose incidence among accessions, especially in season I.

MCP ranged from 7.2 to $10.3 \mathrm{~g}$ in season I and from 6.3 to $11.1 \mathrm{~g}$ in season

Table 2. Area under the disease progress curve (AUDPC) for the Common Bacterial Blight in 25 bush-type snap beans accessions inoculated with Xanthomonas axonopodis pv. phaseoli (Xap) and X. fuscans subsp. fuscans (Xff). Londrina, UEL, 2013.

\begin{tabular}{|c|c|c|}
\hline Genotypes & Xap & $X f f$ \\
\hline UEL 402 & $98.50 \mathrm{~A}$ & $101.83 \mathrm{~A}$ \\
\hline UEL 403 & $86.25 \mathrm{~A}$ & $104.67 \mathrm{~A}$ \\
\hline UEL 404 & $74.07 \mathrm{~B}$ & $100.29 \mathrm{~A}$ \\
\hline UEL 405 & $93.19 \mathrm{~A}$ & $100.81 \mathrm{~A}$ \\
\hline UEL 407 & $64.79 \mathrm{~B}$ & $87.29 \mathrm{~B}$ \\
\hline UEL 408 & $75.50 \mathrm{~B}$ & $100.63 \mathrm{~A}$ \\
\hline UEL 409 & $68.00 \mathrm{~B}$ & $90.50 \mathrm{~B}$ \\
\hline UEL 411 & $74.83 \mathrm{~B}$ & $97.00 \mathrm{~B}$ \\
\hline UEL 412 & $70.31 \mathrm{~B}$ & $95.83 \mathrm{~B}$ \\
\hline UEL 415 & $99.00 \mathrm{~A}$ & $85.17 \mathrm{~B}$ \\
\hline UEL 416 & $89.79 \mathrm{~A}$ & $103.93 \mathrm{~A}$ \\
\hline UEL 417 & 79.83 B & $104.67 \mathrm{~A}$ \\
\hline UEL 420 & $81.55 \mathrm{~A}$ & $102.11 \mathrm{~A}$ \\
\hline UEL 424 & $79.55 \mathrm{~B}$ & $94.20 \mathrm{~B}$ \\
\hline UEL 427 & $87.94 \mathrm{~A}$ & $103.78 \mathrm{~A}$ \\
\hline UEL 429 & $88.56 \mathrm{~A}$ & $106.89 \mathrm{~A}$ \\
\hline UEL 431 & $74.19 \mathrm{~B}$ & $96.75 \mathrm{~B}$ \\
\hline UEL 436 & $99.35 \mathrm{~A}$ & $112.05 \mathrm{~A}$ \\
\hline UEL 441 & $90.86 \mathrm{~A}$ & $105.14 \mathrm{~A}$ \\
\hline UEL 445 & $83.00 \mathrm{~A}$ & $105.70 \mathrm{~A}$ \\
\hline UEL 446 & $84.50 \mathrm{~A}$ & $102.25 \mathrm{~A}$ \\
\hline UEL 447 & $73.67 \mathrm{~B}$ & $103.33 \mathrm{~A}$ \\
\hline UEL 1 & $84.00 \mathrm{~A}$ & $98.67 \mathrm{~B}$ \\
\hline UEL 2 & $74.20 \mathrm{~B}$ & $117.20 \mathrm{~A}$ \\
\hline Alessa & $104.25 \mathrm{~A}$ & $114.67 \mathrm{~A}$ \\
\hline
\end{tabular}

Means followed by same capital letters in the column do not differ significantly from each other by Scott-Knott test, $5 \%$.

II, and no significant differences among accessions were detected by the ScottKnott test in season I. In season II, MCP differed significantly among accessions: UEL 403, UEL 404, UEL 412, UEL 415, UEL 416, UEL 417, UEL 420, UEL 424, UEL 427, UEL 429 and UEL 446 having the heaviest pods.

Yield varied between 5.14 and 9.72 and between 7.02 and $11.07 \mathrm{t} / \mathrm{ha}$ in seasons I and II, respectively. The Scott-Knott test grouped ten and 15 accessions in the top classes in seasons I and II, respectively, with accessions UEL 402, UEL 405, UEL 407, UEL 408, UEL 412, UEL 417 and UEL 420 appearing in both seasons (Table 1). Yield observed here was higher than that reported by Moreira et al. (2009). Pinto et al. (2001), evaluating the best harvest age for snap beans, cultivar Novirex, under conventional farming, reported the highest commercial pod yields between 8.6 and $10.1 \mathrm{t} / \mathrm{ha}$.

There are no breeding programs of bush-type snap beans specific for organic farming. In the present work, accessions UEL 402, UEL 405, UEL 407, UEL 408, UEL 412, UEL 417 and UEL 420 have shown to be promising both as cultivars for organic farming in the region and as advanced germplasm in breeding.

The analysis of variance of the area under the disease progress curve (AUDPC) revealed significant differences and wide variability among accessions when inoculated with the two Xanthomonas isolates (Table 2). Average AUDPC values were 82.09 
(64.79-104.25) and 101.17 (85.17117.2) for X. axonopodis pv. phaseoli (Xap) and X. fuscans subsp. fuscans $(X f f)$, respectively, indicating that $X f f$ was the most pathogenic. This is consistent with Mutlu et al. (2008), who also verified higher virulence of $X f f$ when compared to Xap in beans.

All accessions were moderately susceptible to the common bacterial blight (CBB) within 30 days after we started assessing the disease. Nevertheless, there were isolate-specific reactions. Accessions UEL 404, UEL 408, UEL 409, UEL 411, UEL 412, UEL 417, UEL 424, UEL 431, UEL 436 and UEL 2 had the lowest AUDPC values for CBB-Xap; while accessions UEL 407, UEL 409, UEL 411, UEL 412, UEL 415, UEL 424, UEL 431 and UEL 1 had the lowest scores for CBB-Xff (Table 2). CBB resistance in $P$. vulgaris has complex nature, oligo or polygenic inheritance, and is strongly affected by the environment (Ferreira et al., 2003). More than 20 QTLs related to CBB resistance, with variable genetic effects, are distributed across all eleven beans chromosomes (Kelly et al., 2003; Santos et al., 2003). Trindade et al. (2012), evaluating the resistance of 14 snap beans accessions to two $X$. axonopodis pv. phaseoli isolates, found that only accession UENF 1482 showed good performance, since it did not differ significantly from resistant genotypes PI 207262 and BAC 6. The presence of $\mathrm{CBB}$ resistance genes in common beans genetic background is an important tool for strategies that intend to breed snap beans for resistance via crosses with selected parents. Among accessions evaluated in the current work, only accessions UEL 407 and UEL 412 combined low AUDPC and high yield. Even then, the introgression of resistance genes, as for example those available in accessions PO 207262 and BAC 6 (common bean), into these accessions are still necessary.

\section{ACKNOWLEDGEMENT}

Authors acknowledge the support of the State University of Londrina and of the Araucária Foundation in implementing this research.

\section{REFERENCES}

BIANCHINI,A; MARINGONI,AC; CARNEIRO, SMPG. 2005. Doenças do feijoeiro (Phaseolus vulgaris L.). In: KIMATI, H; AMORIM, L; REZENDE, JAM; BERGAMIN FILHO, A; CAMARGO, LEA. (eds). Manual de Fitopatologia. São Paulo: Editora Ceres. p.333-349.

CARGNELUTTI FILHO, A; STORCK, L; RIBEIRO, ND. 2009. Medidas da precisão experimental em ensaios com genótipos de feijão e de soja. Pesquisa Agropecuária Brasileira 44: 1225-1231.

EFSA PPH (EFSA Panel on Plant Health). 2014. Scientific opinion on the pest categorization of Xanthomonas axonopodis pv. phaseoli and Xanthomonas fuscans subsp. fuscans. EFSA Journal 12: 3856, 30.

FAO. 2015, 20 de junho. Statistical databases - Agriculture. Rome: FAO. Available in http:www//apps.fao.org

FERREIRA, CF; PEREIRA, MG; SANTOS, AS; RODRIGUES, R; BRESSAN-SMITH, RE; VIANA, AP; DAHER, RF. 2003. Resistance to common bacterial blight in Phaseolus vulgaris L. recombinant inbred lines under natural infection of Xanthomonas axonopodis pv. phaseoli. Euphytica 134: 43-46.

KELLY, JD; GEPTS, P; MIKLAS, PN; COYNE, DP. 2003. Tagging and mapping of genes and QTL and molecular marker-assisted selection for traits of economic importance in bean and cowpea. Field Crops Research 82: 135-154.

KIRK, AP; FOX, SL; ENTZ, MH. 2012. Comparison of organic and conventional selection environments for spring wheat. Plant Breeding 131: 687-694.

LUBY, CH; LYON, AH; SHELTON, AC. 2013. A new generation of plant breeders discovers fertile ground in organic agriculture. Sustainability 5: 2722-2726.

MAPA. 2015, 09 de maio. Cadastro nacional de produtores orgânicos. Available in http:// www.agricultura.gov.br/desenvolvimentosustentavel/organicos/cadastro-nacional//

MASON, HE; SPANER, D. 2006. Competitive ability of wheat in conventional and organic management systems: a review of the literature. Canadian Journal of Plant Science 86: 333-343.

MIKLAS, PN; COYNE, DP; GRAFTON, KF; MUTLU, N; REISER, J; LINDGREN, DT; SINGH, SP. 2003. A Major QTL for common bacterial blight resistance derives from the common bean great northern landrace cultivar Montana $\mathrm{n}^{\circ}$ 5. Euphytica 131: 137-146.

MOREIRA，RMP； FERREIRA，JM; TAKAHASHI, LA; VASCONCELOS, MEC; FEUS, LC; BOTTI, L. 2009. Potencial agronômico e divergência genética entre genótipos de feijão vagem de crescimento determinado. Semina 30: 1051-1060.

MUTLU, N; VIDAVER, AK; COYNE, DP; STEADMAN, JR. 2008. Differential pathogenicity of Xanthomonas campestris pv. phaseoli and $X$. fuscans subsp. fuscans strains on bean genotypes with common blight resistance. Plant Disease 92: 546-554.

MYERS, JR; BAGGETT, JR. 1999. Improvement of snap bean. In: SINGH, SP (ed). Common bean improvement in the twenty-first century. Netherlands: Springer. p.289-329.

PASTOR-CORRALES, MA; BEEBE, SE; CORREA, FJ. 1981. Comparing two inoculation techniques for evaluating resistance in beans to Xanthomonas campestris pv. phaseoli In: INTERNATIONAL CONFERENCE ON PLANT PATHOGENIC BACTERIA. Cali: CIAT. p.493-503.

PINTO, CMF; VIEIRA, RF; VIEIRA, C; CALDAS, MT. 2001. Insumos e cultivares em teste: idade de colheita do feijão-de-vagem anão cultivar Novirex. Horticultura Brasileira 19: 163-167.

RAVA, CA; SARTORATO, A. 1994. Crestamento bacteriano comum. In: SARTORATO, A; RAVA, CA (eds) Principais doenças do feijoeiro comum e seu controle. Brasília: Embrapa-SPI, p.217-242.

RESENDE, MDV; DUARTE, JB. 2007. Precisão e controle de qualidade em experimentos de avaliação de cultivares. Pesquisa Agropecuária Tropical 37: 182-194.

RODRIGUES NETO, J; MALAVOLTA, JR; VICTOR, O. 1986. Meio simples para o isolamento e cultivo de Xanthomonas campestris pv. citri tipo B. Summa Phytopathologica 12: 16.

SANTOS, ASS; BRESSAN-SMITH, RE; PEREIRA, MG; RODRIGUES, R; FERREIRA, CF. 2003. Genetic linkage map of Phaseolus vulgaris L. and identification of QTLs responsible for resistance to Xanthomonas axonopodis pv. phaseoli. Fitopatologia Brasileira 28: 5-10.

SILVA, FC; SOUZA, RM; ZACARONI, AB; LELIS, FMV; FIGUEIRA, AR. 2013. Otimização da técnica de PCR para a detecção de Xanthomonas axonopodis pv. phaseoli em sementes de feijão. Summa Phytopathologica 39: 45-50.

SPAGNUOLO, FA; GONCALVES, SAG; FREITAS, FM; VENTURA, MU; MIGUEL, ALA; SOUZA, NV; HATA, FT. 2016. Melhoramento participativo do tomateiro sob manejo orgânico. Horticultura Brasileira 34: 183-188.

TRINDADE, RS; RODRIGUES, R; AMARAL JÚNIOR, AT; GONÇALVES, LSA; DAHER, RF; SUDRÉ, CP. 2012. Critical disease components of common bacterial blight to effectively evaluate resistant genotypes of snap bean. Journal of General Plant Pathology 78: 201-206.

TRINDADE, RS; RODRIGUES, R; AMARAL JÚNIOR, AT; GONÇALVES, LSA; VIANA, JMS; SUDRÉ, CP. 2015. Combining ability for common bacterial blight resistance in snap and dry bean (Phaseolus vulgaris L.). Acta Scientiarum 37: 37-43.

VIDAL, VL; JUNOUEIRA, AMR; PEIXOTO, N; MORAES, EA. 2007. Desempenho de feijãovagem arbustivo, sob cultivo orgânico em duas épocas. Horticultura Brasileira 25: 10-14.

WILLER, H, KILCHER, L. 2012. The world of organic agriculture: statistics and emerging trends 2012. FiBL, IFOAM. 